\title{
Theory and Practice in Criminal Law ${ }^{1}$
}

A lawyer, and especially a professor of law, should not speak in paradoxes, because paradoxes arouse mistrust and may undermine the authority of the person who uses them. However, it is not always the case that a paradox is merely a flashy display of words; occasionally it may convey some real meaning. Hence, when writing on theory and practice in criminal law, I shall use a formulation that I consider right, relying on my experience and having given it a lot of thought, although it will take the form of a paradox.

First, however, I shall make a few comments that are in part personal and in part relate to the subject at hand. I cannot assume the role of a representative of this or that side, I rather stand between them, in the middle, as my current position does not abrogate my work as a judge for over a decade. I am, therefore, equally close to both sides. By 'practice' I do not mean people (judges, defence counsel, public prosecutors) but rather the current legislation together with the judicial decisions, with regard to which statutory provisions leave little room for discretion. Therefore, my comments cannot concern the so-called practitioners of criminal-law, but I may only mention that I would like to see more criticism on their part than is evident in the current state of affairs.

1 Translated from: J.J. Bossowski, Teoria i praktyka w prawie karnym, "Ruch Prawniczy, Ekonomiczny i Socjologiczny" 1924, 6 by Tomasz Żebrowski and proofread by Stephen Dersley and Ryszard Reisner. The translation and proofreading were financed by the Ministry of Science and Higher Education under 848/2/P-DUN/2018. 
By theory, I mean law as it should be in statu nascendi. Now I come to the point, that is, to the paradox I mentioned. At present, theory is practical, and practice is theoretical. Before anyone takes aim at me, let them read the subsequent comments on which I base my views, with each of these comments deserving to be made the subject of a dissertation.

The practice of law still demands that punishment should be based on guilt and retribution. ${ }^{2}$ Thus, it is on a wild goose chase, because the determination of guilt (degree of guilt) in a specific case and the adjustment of retribution (intensity of retribution) to the degree of guilt is not humanly possible. This is a hangover from the times when criminal law was based on philosophical abstractions, or was derived from them. Theory demands that criminal law be based on the aspect of purposefulness: criminal law is bring about the defence of society against criminals, while the nature and limits of this defence are to be indicated by experience (criminal statistics) and the observation of life (in particular the observation of the milieu criminel, i.e. the sociological aspects and the observation of a criminal's psyche). This entails a transition to the 'straightforward story' of facts and conclusions based on facts.

Duo si faciunt idem, non est idem. This necessary principle of justice is recognised by practice, with some reservations, not due to any fault of its own, but because it is compelled by statute. In the case of murder, ${ }^{3}$ it does not matter for either the terminology of the act or punishment (the death penalty is always prescribed, without exception) whether the crime was committed purely due to inhuman savagery or for some quite different reason (e.g. unhappy cohabitation, jealousy, etc.), or whether it was the result of a criminal psyche (an individual posing a constant threat to society, one who will commit another murder soon

2 Retribution as an element of revenge is the backbone of present-day law, with some of its provisions strongly emphasising this aspect. For instance, French regulations accord priority seats to the parents of a victim at the execution of the murderer.

3 Under the statute in force in the Recovered Territories; analogous instances can be found in other provincial statutes. 
if they remains at large). Moreover, whether the above resulted from an unhappy coincidence that upset the perpetrator's moral balance (the socalled occasional criminal whose trials and tribulations before and after the act and the act itself break them down completely, an individual who will not commit a second murder even if, due to the circumstances, they are not punished and remain at large).

I have chosen a particularly extreme example but nevertheless, practice must (because it is compelled by statute) squeeze crimes into the statutory formulae that only conventionally take into account the perpetrator-related aspects (kinds of guilt) and ignore the whole gamut of the perpetrator's mental properties. On the other hand, theory follows the following line of thought: punishment will be purposeful, i.e. it will serve its purpose of social defence if an individually designated criminal (person A or B) is either deterred, corrected or neutralised. To find out which of these goals is achievable and advisable, it is necessary to get to know the criminal who is on trial as a living person and classify their psyche (occasional criminal, habitual criminal, incorrigible criminal or one capable of being corrected). It is not enough to establish that the facts in the case, established in evidentiary proceedings, fit the statutory construction of the crime. Obviously, only a purposeful punishment may constitute an effective punishment, i.e. serving its function.

An alcoholic offender, or a criminal with diminished responsibility will receive a more lenient punishment than that given to a normal criminal, because their guilt is less than that of normal criminals. This is right and logical, as long as guilt is held to be the cornerstone of criminal law. But what results does this bring for society? Such a criminal is undoubtedly more dangerous to society than a normal criminal, hence social defence must be stronger in this case, not weaker. A reaction to the criminal act will be purposeful only if the criminal is either cured or (if this is not possible) neutralised. Whether this reaction will be called a sanction (as in the Italian draft), a preventive measure, or 
will be referred to by some other name, is for the editors of the code to decide. The content does not depend on the name, and this content must replace the completely pointless punishments hitherto meted out in such cases.

There is a similar state of affairs with incorrigible criminals. Today's legislation has no cognisance of this type of criminal, but it does nonetheless exist. Criminal statistics and the experience of judges show this quite clearly. Practice will mete out a harsher punishment for a repeat offence or compulsive criminality than in ordinary cases, but the punishment will not attain the goal it must necessarily pursue, for it will not neutralise an incorrigible criminal. The sentence will come to an end, and the state authorities will, in Liszt's words, set this criminal free like a wild animal about to attack society. Such criminals are eternal revolutionaries, harming the legal order. The chances that they will adapt to social life are nil; they are the incarnation of imminent danger to society. Impossible to deter or correct, their murderous energy must simply be incapacitated. Therefore, in this area, theory juxtaposes the completely ineffective and overly lenient treatment accorded to incorrigible criminals with the practice of casting them outside society (artificial selection) through long-term or even life sentences (Liszt's opinion).

There is great divergence in the views on juvenile delinquency. For theory, the only purposeful response lies in educational and educationalcorrectional measures, and this maybe accompanied by favourable results obtained by such measures in other countries. Moreover, theory can claim that some of its postulates have been realised in the current legislation. In contrast, practice tends to take a rather sceptical stance, with practitioners sometimes calling for corporal punishment (these are not isolated calls). I will avoid joining the general discussion as to whether corporal punishment is a suitable penal measure (personally, I am certain that it is not). I shall only mention important mental aspects. In the era when the average citizen of a state was accorded only 'limited capacity for reasoning, as a subject', while the absence of political life, or restric- 
tions in this regard, prevented any development of individuality, thus forcing an individual to content themselves with a predefined career, a certain effectiveness was enjoyed by exclusively coercive measures, as they proved effective for weak individuals. Now, when political life is fully developed (or even hyper-developed), as respect for individuality has been introduced into all walks of life, no brutal measure (such as flogging) can be used, and it will not be acknowledged that putting constant pressure on the will of the individual has any pedagogical or penal value. Only such measures that have a lasting and positive effect on the psyche (character training, improvement of conduct) can be described as effective. Corporal punishment does not belong to such measures; nor can it attain another goal of punishment, namely neutralisation.

The negative opinions of German courts and public prosecutor's offices concerning the conditional suspension of sentences are well-known (in this, case, practice was supported by some representatives of theory). However, suspended sentences are supported not only by the favourable experiences of Western-Romanic and English-speaking countries, but also by psychological aspects. In the case of a suspended sentence, the rehabilitation of criminals (at least, so-called civic rehabilitation) coincides with their obvious interests, as a result of which the impulse of a criminal instinct meets with a strong counter-impulse. Moreover, the State makes prudent use of the deterrent power of imprisonment on individuals who have not suffered this punishment before (it is such individuals that are at issue here). The deterrent power, if used reasonably, is a strong positive factor acting on the criminal whose sentence has been suspended, while it is lost forever without effect once a sentence is served. A criminal who has served time in prison is like a traveller in the Latin proverb who cantabit coram latrone as he has already nothing to lose.

The measure of the value of current legislation is its construction, while the measure of the value of new law must be its effectiveness, i.e. criminal statistics. Attempts have been made to coin the term 'law to 
combat crime' (Thomsen) to underscore the law's practical character. On numerous occasions, overestimating ${ }^{4}$ the aspect of legal construction has led to practice being uselessly overburdened. I shall restrict myself to one example. Theft and embezzlement are so close to each other in terms of content and social significance that Liszt believed they could be fused into a single offence. However, their different constructions, based on a doubtful criterion of differentiation, forced the courts, in a great number of instances, to conduct painstaking findings of fact (despite the offence being self-evident) and cite convoluted legal arguments, theoretically often valuable and subtle, but not producing any positive social effect. The purposefulness and effectiveness of punishment was not and cannot be helped by such work.

Theory demands that the languages of the criminal code and of the courts be made more democratic. The language of the code should be intelligible to a citizen of the State. The current style of statutes does not fulfil this criterion. Many clauses in this or that provincial statute require comments by legal scholars and judicial decisions; even a lawyer would not be able, relying on the text of a local statute alone, to determine what the following are: a commencement of execution, violence to the person, concentration, insult, etc. The definitions of fraud are excessively complicated in all provincial statutes, despite the fact the essence of act is quite straightforward. The establishment of juries in those provinces where they are unknown (former Russian and German ones) will probably occur in the near future. When this happens, throughout Poland we will encounter a phenomenon all too familiar to practice in Małopolska, namely that of jurors being unable to comprehend questions posed to them, due to their muddled and unintelligible formulation. This is unavoidable, since it is due to the language of a statute. If the formulation of a norm itself

4 I use the word 'overestimate', because construction is necessary; if it were not there, pernicious arbitrariness would arise; overestimating construction, in turn, is pernicious, too, as it overshadows other aspects that are equally important and relevant for criminal law. In addition, it leads to excessive subtlety in defining legal concepts, which is believed to be the hallmark of legal studies and judicial decisions. 
(a statutory prohibition) is not felicitous, the need to use the statutory definition of an attempt to aid and abet exacerbates this defect further and produces the following question: 'Is A guilty of intentionally making person $\mathrm{B}$, with a gift or otherwise, divulge his intention to take the life of person $\mathrm{C}$ through intentional acts, but done without premeditation, that comprise the commencement of the execution of the crime of homicide?' (An example given by Rosenberg in his dissertation on juries). I do not think that any lawyer will call this question overly clear and easy. Hence, it is vital to simplify the language of statutes. Equally vital is the need to simplify the language of the courts, both in terms of speech and writing. In this case, the change is straightforward, as it depends solely on the will of practitioners, whereas the language of statutes and a defective statute are inherited by humanity (as Mephisto correctly explained to a scholar), as chronic diseases from generation to generation.

Nonetheless, no tendency towards change can be noticed in practice, or even a sense of how much a change is needed. The language of the courts (especially the language of interviews and records) should be flexible and capable of adjusting to the intellectual and linguistic level of the interviewee. Instead, only too often do we come across legal expressions in the interview records whose colloquial meaning differs considerably from their legal meaning, or which are practically unknown to those outside the legal profession. We encounter such expressions as 'criminal decision', 'consideration', etc. And yet it is the witness who is responsible for the contents of a record, on pain of criminal liability; while the defendant has the procedural right to have their explanations faithfully recorded, and it is this faithfulness that is so easily distorted when these explanations are pointlessly translated into legal-judicial jargon. That this is not just a shortcoming of our practice is evident from the many comments by Anatole France on French practice. It goes without saying that putting a question to a witness that contains a legal term may lead to many results other than actually revealing the truth. 
Theory assigns criminalistics (or forensics — scientific crime detection) an important place in criminology and demands that a university chair be founded for this science, along with other criminological sciences. Meanwhile, as a rule impractical practice does not care much ${ }^{5}$ about this body of decidedly practical knowledge, despite the availability of accessible literature (French works by Reiss, Goddefroy, Locard, Gardenat, German ones by Gross, Gross-Höpler and Heindl, a valuable pamphlet in Polish by Olbrycht $O$ postępowaniu z dowodami rzeczowymi, and books by Łukomski and Stepek-Krystańczyk). Criminalistics is not part of a judge's examination and I have absolutely no knowledge (I would prefer to be wrong) of opinions emanating from the circles of practitioners that demand a change. Thus, you can be an examining magistrate with no knowledge of forensics. In effect, the best pieces of evidence (so-called exhibits) are wasted, because the judge either does not take any notice of them or 'misreads' the material placed before the court, instead of making effective use of it. Knowledge of forensics therefore is a must for a judge (an examining magistrate or a judge hearing criminal cases), defence counsel and public prosecutor.

How radically theory has given up the old method of abstract treatment of problems can be seen in the fact that opinions are voiced by its representatives (Dernburg, Zitelmann, and recently Kantorowicz in: Zukunft des Strafrechtes by Dehnow) suggesting that law studies should be divided into three stages, by inserting between the initial theoretical course and final theoretical-practical course, a two-year practical programme of study. A curriculum which is-evidently-clearly not theoretical.

5 Of course, I have to recognize that in some cases forensic knowledge is used. However, the view expressed in this text is based on personal observations made while reviewing many statutes, coming from various provinces and information communicated to me by several professors of forensic medicine (v. also the pamphlet by Prof. Olbrycht mentioned in the text). I would consider it normal if every case were examined from the point of view of criminalistics, because only then would it be guaranteed that many and the best pieces of evidence are not lost to no avail. 
Practice is concerned with the course of criminal proceedings from the moment they are instituted until their valid termination. What happened before the proceedings, because of a specific crime, and what will happen once they are terminated is of no concern to practice. The period when a criminal was on the skids, as it were, drifting towards crime, the individual or social factors that bore upon them at this time, the effectiveness or ineffectiveness of punishment once the proceedings are over, in particular finding that the criminal has improved or they are incorrigible, or indeed the ethical and mental experiences of the convict while serving time in prison - these are the aspects which a judge believes to be only loosely related to his profession.

This is a highly undesirable narrowing of horizons, because criminal proceedings are only an intermediate link between the time when a crime is imminent, and the sentence is carried out. This is the link that is the most closely tied to the preceding and following ones. The purposeful dimension of punishment is not possible without learning about the individual and social aspects of a criminal's life prior to a crime; criminal proceedings are a quite unnecessary outlay of labour if they do not bring any results over a longer period. Therefore, criminology broadens the horizons in two directions: it shows that it is necessary to deal preventively with the individual who is falling into crime, and demands that the stage of administering punishment be considered equally important with court proceedings.

Rejecting prevention would be just as unreasonable as rejecting hygiene in medicine and limiting oneself to treatment. Prevention saves not just individuals, but also interests that would fall victim to a crime. What bodies should be entrusted with prevention? Perhaps it should be made the responsibility of civic patrons or administrative authorities or, possibly, court divisions set up for this purpose. This is a question of the legislative technique, but it must be admitted that punitive measures alone will not suffice to combat crime. Theory (Roux) pins hopes on creating administrative prohibitions, removing 
opportunities to commit crimes due to a lack of self-control or because of an easy opportunity (facilités criminelles, for instance public sales in great department stores).

The administration of punishment is still considered a mechanical enforcement of the letter of the sentence; facts revealed during the administration of punishment or events that happened in the course of it may not (unless they reveal a miscarriage of justice) have a retroactive effect on the judgment; the only thing they can do (provided they are positive and important) is bring about an administrative pardon. And yet only in the course of the punishment that it is possible to determine if it is effective, or what other punishment would be needed and effective. Such a diagnosis can only be made after a long observation of the convict's psyche and the effect punishment has on them. In the course of a trial such observations cannot be made, hence the strict administration of punishment defined by the sentence (which is the provision of the current legislation) has too many characteristics of a conjectural and accidental nature.

These practical considerations gave rise to the idea of moving the exact determination of the severity of the punishment to the stage of its administration and requiring that the sentence indicate the punishment approximately, by specifying its lower and upper limits (so-called indeterminate sentences). Then, the final determination of punishment would have to be preceded by a detailed examination and observation of the convict. In this way, accidents and conventional solutions could be avoided. This idea was born in a country of thoroughly realistic concepts: America. It is being applied in the Polish draft bill on juvenile courts to the determination of the severity of correctional measures.

I would like these comments to help rectify false opinions on criminal law that are in the making. It is assumed that it will be a theoretical construct, a utopian one in its humanitarianism, and thus ineffectual. I wish to dispel this myth. It will be much harsher than the current one 
where needed (with respect to incorrigible criminals) and if it brings about a shift in other fields from the current pointless and ineffective harshness (e.g. the use of penal measures with respect to juvenile offenders) to crime prevention, it will satisfy the demands of culture for the benefit of society.

In a few years' time, a unified criminal law, based on new ideas, will be ready. Then practice will face a difficult task: it will have to bridge the huge gap between the old and new law, reject the dogmas that have run in its blood for generations, and absorb new ideas to be able to put them into action. We all hope that this task will be completed in the best way possible, for the benefit of the State. It would be beneficial to cast off now everything that is not required by the present statute but which is merely an inherited anachronism.

Perhaps now the paradox with which these comments started will not seem too shocking. Besides, paradoxes and criminology are genetically closer than it seems; after all, the modern master of paradox left his mark (albeit a sad one) on the history of criminology.

A few more words. It is all too easy to be misunderstood and unwillingly strike the chord of one's professional or personal sensitivity in spite of the fact that one speaks with an eye to objective reasons and arguments. I do not want my comments to be taken as the criticism of those who administer the law (judges or state prosecutors) that under difficult conditions, struggling against the shortage of personnel, perform their important tasks. That the point here is not criticism I mentioned at the outset; the lion's share of the above-mentioned shortcomings is a result of the current legislation. I must emphasise that it is the new law (and its supporters) that demands that those who administer the law be assigned a still more important and independent role than their current one. Those who administer the law are to be not only (as today) 'servants of the statute' or an instrument that blindly applies a statutory provision. Instead, knowing, understanding and assessing 
life, in all its manifestations and living people, they should be a factor in the development of law ${ }^{6}$ — next to statute drafters — and not only guard the provisions of statutes, but also achieve its long-term objectives. It is my strong desire and wish for the law enforcement authorities to muster and find the 'will power' necessary for future actions. It is only fitting to apply to my comments the motto: honny soit qui mal y pense.

6 For instance, a German draft bill leaves to the judge's discretion, in the case of an inapt attempt, not only what kind and the severity of punishment should be inflicted, but also if it should be inflicted at all. Moreover, there is an observable tendency to institute and expand the so-called judge-granted pardon. It is found in the Polish territory only in the former Russian partition by virtue of the Transitional Provisions. 